\title{
Measuring Efficiency Of Commercial Banks In The Gambia
}

\author{
Dr. Seeku A. K. Jaabi \\ First Deputy Governor, Central Bank of The Gambia, \\ Banjul and Abubacarr Fatty, Phd Candidate, \\ Umm Al-Qura University, Turkey \\ Babucar Malang Fatty \\ Banking and Finance, Ankara Yidirim Beyazit University, Turkey
}

\begin{abstract}
The long-term sustainability of commercial banks depend largely on how efficiently they are managed. This study explores the relative efficiency of commercial banks in the Gambia, by examining the banks' operational characteristics on efficiency measures. The study critically examines the efficiency levels of seven commercial banks (six conventional banks and one Islamic bank) in The Gambia from 2005 to 2009 using the Data Envelopment Analysis (DEA) methodology to examine selected banks' relative efficiency levels. Also, using Tobit regression model, the study examines the relationship between banks' specific characteristics (i.e banks size, profitability and market power) and efficiency measures - Technical Efficiency (TE), Pure Technical Efficiency (PTE) and Scale Efficiency (SE). The results from DEA exhibit that the majority of Gambian banks are fully efficient under the assumption of VRS. The findings showed that Trust Bank Ltd (TBL) was the most efficient bank while International Commercial Bank (ICB), the least efficient bank during the period. The results of Tobit Regression Model showed only bank size is significantly and positively related to TE and SE, while both profitability and market power were negatively associated with TE and $S E$, indicating no relationship between profitability and market power with efficiency measures in Gambian banking industry.
\end{abstract}

Key Words: Efficiency, commercial banks, Islamic bank, Technical, Scale JEL Code: D01, D02, D53, G21

\section{INTRODUCTION}

The importance of the commercial banking sector in the financial environment of any economy has motivated the researchers to enquire into the determinants of bank efficiency. However, it is difficult to measure output, technical change or productivity growth in commercial banking as a service industry. For this reason, there have been disagreements over which banks' services and how to measure them. Banking also remains a highly regulated industry in which substantial inefficiencies have been shown to exist. As a result, technical improvements that increase the productivity of the most efficient firms may not be well reflected in the industry as a whole. A further complication is that the deposit side of banking underwent substantial deregulation in the 1980s-90s, including the lifting of effective interest rate ceilings on deposits, loans and the creation of new types of accounts. The deregulation directly raised banking costs and shifted the optimal mix between the provision of services and the payment of interest to depositors. Measurement of cost changes and productivity gains must take these factors into account, including the possibility of a period of significant disequilibrium as banks attempted to adjust to deposit deregulation.

Despite these difficulties, it is important to analyze the banking industry, as it continues to play an important part in the economy. In addition, the externalities that banking generates 
through its roles as the nation's primary financial intermediary and conduit for monetary policy. Banks are considered important enough to require substantial government protection and supervision. Due to strict regulation, revenues are earned by paying less than the opportunity cost of funds on deposits. Further implicit earnings accrue to the bank on a loan when additional balances are kept with the bank for liquidity, clearing, or timing and prudential reserve requirement purposes (Berger \& Humphrey, 1992).

Commercial Bank is a financial institution that provides multiple banking services to vast number of people. In today's world, banks operate in an increasingly competitive environment (Isik \& Hassan, 2002b; Yeh, 1996). Thus, long-term capability of these banks depends partly on how efficiently they are managed (Mester, 1997). In this regards, the main objective of every bank manager is to use the resources in an efficient and effective manner. This has been very much relevant in global movements such as increasing competition for financial services, deregulation, technological innovations and banking consolidation has brought more consciousness on controlling costs and providing products and services more efficiently (Spong, Sullivan, \& DeYoung, 1995). Commercial banking efficiency is important at both macro and micro levels and in order to allocate resources effectively, banks should be sound and efficient (Siyaka, 2008).

Efficiency is defined as the relationship between what a firm produces and what it could possibly produce, under the assumption of full utilisation of the resources (Hoyo et al., 2004). 'Efficiency is the degree of success that producers achieve in allocating the available inputs and the outputs they produce, in order to achieve their goals, namely high degree of efficiency in cost, revenue, or profit' ( Kokkinou \& Geo., 2009:15).

Efficiency in banking industry can be differentiated between allocative efficiency (AE) and technical efficiency (TE). AE is the degree to which resources are being allocated with the highest expected return while TE is a set of outputs using the minimum possible amount of inputs (Siyka, 2008). Several empirical researches have been carried out in the US, Europe and Asia, yet only a few on banking industry in Africa and none on The Gambia ${ }^{1}$, in particular. Therefore, the objective of this study is to examine the efficiency of commercial banks in Gambia. The study is divided into six parts, starting with an introductory section followed by a brief background of the banking industry. Literature review comes next followed by Methodology adopted in the study. Section five presents the data analysis, with conclusions and implications of the study closing the paper.

\section{BACKGROUND OF THE GAMBIA'S BANKING INDUSTRY}

The Gambia ${ }^{2}$ has experienced fundamental changes over the last two-three decades in the banking industry with significant financial sector reforms during the period of structural

\footnotetext{
1 There is only one study of banking sector in the Gambia - the study of (Agu, 2004) which focused only on the functions of a financial sector in the Gambia using industry data. This study seeks to determine the relationship between banks' characteristics (Bank's Size, Profitability and Market Power), and efficiency measurements of seven banks including an Islamic bank.

2 The Gambia is located midway on the bulge of the West African Coast, stretching $350 \mathrm{~km}$ from West to East on either side of the Gambia river. The country varies in width from about $50 \mathrm{~km}$ near the mouth of the river to about $24 \mathrm{~km}$ inland. The Gambia covers a total land area of 10.368 square kilometres and, with the exception of its Atlantic Coast, is entirely surrounded by Senegal. The River Gambia from which the country derives its name intersects it. It has a population of 1,336,320 (2001 Census) with an estimated growth rate of $4.2 \%$ per annum. Like most African countries at independence, The Gambia in 1965 inherited a small but open economy, relying on primary agricultural product groundnuts for its exports. Structurally, agriculture is the backbone of the Gambian economy with more than 75 per cent of the population engaged in subsistence farming. The share of the manufacturing industry to Gross Domestic
} 
adjustment programme (SAP) and programme for sustained development (PSD) to include among others; financial liberalisation and decentralisation, institutional development and enhancing the stability of the financial sector. There are strict rules of entry into banking industry regarding increased capital adequacy, fit and proper test of Shareholders, Directors and Senior Officers, feasibility study, among other stringent requirements There were 12 banks (11 conventional commercial banks (CCBs) and one Islamic bank (IB)) operating in The Gambia in 2008, increasing to 14 banks in 2009 but 2 banks - Oceanic and Prime banks have since ceased operations. Majority of commercial banks in The Gambia are foreign owned with seven Nigerian-owned, two regional, one British, one Malaysian and only one majority Gambian ownership.

Like any other industry, the banking sector in The Gambia had faced challenges in the study period ranging from stiff competition, regulatory and supervisory challenges, impacts of global market, local macro-economic constraints and growth challenges. Apart from the credit instruments to the private sector, government treasury and Sukul Al Salam as the money market instruments are also available investments. With a population of 1.8 million (2013 census) less than 25 per cent have bank accounts. Thus, it is expected that the entry of new banks would enhance financial inclusion, increase competition and efficiency levels of commercial banks in The Gambia. The weaker banks may drop in efficiency level and naturally exit the industry while the strong ones will benefit from increased scale and efficiency levels.

With the increasing number of banks in The Gambia considering the size of the population, many commentators argued that the country is over-banked though no assessment have ever been made to the effect. Prior to proliferation of banks, the existing banks were mainly banking the few corporate bodies, parastatals and few distributive trade activities. Despite the majority of the population (70\%) are found in the agricultural sector and operating small and mediumsized enterprises, they face financing difficulties. With the coming of new regional banks expected to down-scale to incorporate the majority micro, small and medium enterprises, makes the bank efficiency study timely and more relevant.

The banking industry around the world has undergone profound and extensive changes over the last two decades. The globalization of financial markets and institutions which accompanied government deregulation, financial innovations, information revolution and advanced application in communication and technology, has created a competitive banking environment. Due to these developments and changes in the modern banking field, banks try to operate more efficiently in order to stay competitive. There are number of literature on measuring efficiency of banking industry internationally. Indeed, this study, the first its kind attempts to assess the efficiency of commercial banks in The Gambia including an Islamic bank among conventional banks, making this study enriching using non-parametric DEA method of analysis. Furthermore, the study uses the time period 2005 to 2009 due to availability of data for all the banks in the sample.

\section{Theories On Efficiency Of Bank}

\section{LITERATURE}

The concepts of efficiency is derived general from the microeconomic theory of the firm which stated that a firm is fully efficient if it produces at the output level by maximising profits and minimising possible costs (Dong, 2010).

Product (GDP) is miniscule however, tourism and commerce have gained momentum over the years, not only as sources of foreign exchange but also as important source of domestic employment. 
Figure 1 Conceptual Framework On Bank Efficiency Theories

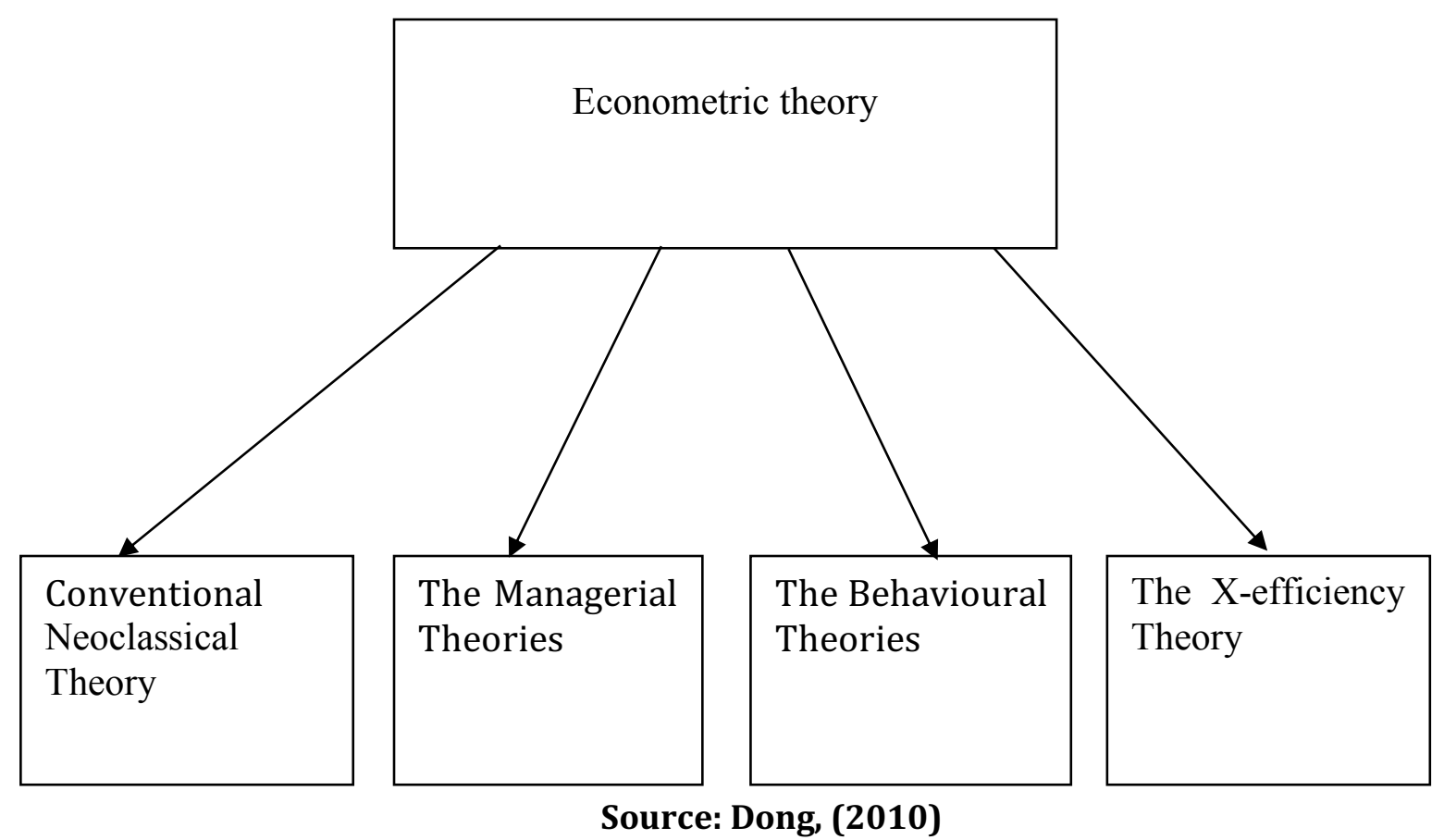

Accordingly, there are four accepted theories that have been used in measuring bank efficiency, namely Conventional Neoclassical Theory, the Managerial Theories, the Behavioural Theories and the X-efficiency Theory.

\section{Conventional Neoclassical Theory}

The Neo-classical theory of the firm stems from the static symmetry framework first developed by Cournot in 1883 (Cohen \& Cyert, 1975; Dong, 2010). The conventional neoclassical theory treats the firm as a black box which transforms resources into profitable goods. This transformation of inputs into outputs is described by a production function. In order words, the conventional neoclassical theory of the firm assumes that the firm is operating in a perfectly competitive market. In this market, all firms seek to maximize profit - simultaneously maximizing revenues and minimizing costs. As a result, a competitive general balance is accomplished by equating the marginal rates of substitute for all firms between any two economic variables (inputs or outputs) ( Dong, 2010) with the inefficient firms driven out of the market.

However, the neoclassical theory has been challenged by managerial theorists such as (Baumol 1959, Marris 1964, Williamson 1964 ), behavioral theorists (Simon 1959, Cyert and March 1963), and X-efficiency theorists (Leibenstein 1966, 1979; Dong, 2010).

\section{The Managerial Theories}

The conventional theory of the profit-maximizing firm has been criticized as being much too impractical and narrow in the modern economy where division of ownership and control exists in large organizations. Managerial theories argue that the controlling management group will follow their own interests and utility, rather than maximizing the profit of the firm, even though they are always subject to some type of profit limitation.

Baumol (1995) and Dong, 2010) introduced the sales-maximization model which argues that the managerial objectives of income, power, prestige, etc are highly associated with sales revenue. Thus, Baumol (1995) suggests that the main goal of management would be to 
maximize sales revenue following achieving some minimum level of profit necessary to satisfy shareholders. Marris (2008) and Williamson (2006) develop a dynamic model of the firm by suggesting that the managerial objective is to concentrate on the maximization of firm growth than maximise profit for shareholders over time.

\section{The Behavioural Theories}

Dong (2010) argues that behavioural theory of firm's ability, need or even wish to maximize profit objective may be questionable as they are faced with uncertainty and lack of full information in the world of business environment. Simon (1995) developed a theory of the firm that emphasizes satisfying and bounded rationality in the decision-making process instead of pursuing a maximization goal.

Cyert \& March (1992) noted that the firm as an organization does not look like a unified structure but an alliance of various participants such as owners, managers, workers and customers with each of the groups or individuals having varying interests and objectives. Furthermore, the firm has five specific objectives - production, inventory, sales, market share, and profit. Some of the objectives may be contradictory; as a result decision-making within the firm is a constant process of bargaining and ambition level. Yet, there may be a discrepancy between the resources available to the firm and the payments required to keep factors in their place. This may increase costs and reduce the overall efficiency of the firm. In practice, the environment is not stationary with increasing challenges such as the flow of technological progress with firms chances of success to reach the technological frontier (Dobbs, 2000; Dong, 2010).

\section{The X-efficiency Theory}

The X-efficiency theory which links with behavioural theory and managerial utility theory was formulated in a succession of Leibenstein's paper in 1998 as cited in.Dong,( 2010) . X-efficiency describes as the general efficiency of a firm given the resources it uses and the best technology available in transforming inputs at minimum cost into maximum outputs. Leibenstein also criticised the neoclassical theory view that firms maximize profit. Indeed, he states that not only that firms cannot maximize profit but that many of them maximize managerial-utility as an alternative (Demsetz, 1997).

Within X-inefficiency theory, Leibenstein (1998) and Dong,( 2010) identified non-maximizing behaviour as the key scheme of X-efficiency. The level of X-inefficiency is mainly determined by the level of effort of individuals within the firm. This study tries to relate these theories to relative efficiency namely TE, PTE and SE in banking industry in the Gambia in order to measure the level of efficiency from 2005 to 2009. The Figure 1 identifies the theories of firm efficiency.

\section{Theoretical Framework Of Efficiency}

Efficiency of CBs depends on economic efficiency approach which is extracted from microeconomic theory of firm, (Debreu 1995 and Farrell 1996) built on the standard framework of production frontier decomposed into scale efficiency, scope efficiency, pure technical efficiency and allocative efficiency. Farrell (1996) developed this economic efficiency idea by considering all inputs and ignoring all index number problems, he divided this productive or economic efficiency of firm into TE and AE (Badunenko, et al 2005, Banker, Charnes, \& Cooper, 1984, Ahmed, 2008). 
TE divided to Pure Technical (PTE) and Scale Efficiency (SE). PTE deals with the use of the unit that assumes constant returns to scale (CRS). A firm using more of both inputs than the combination represented by resources may exhibit variable returns to scale (VRS).

Figure 2 Framework of Efficiency

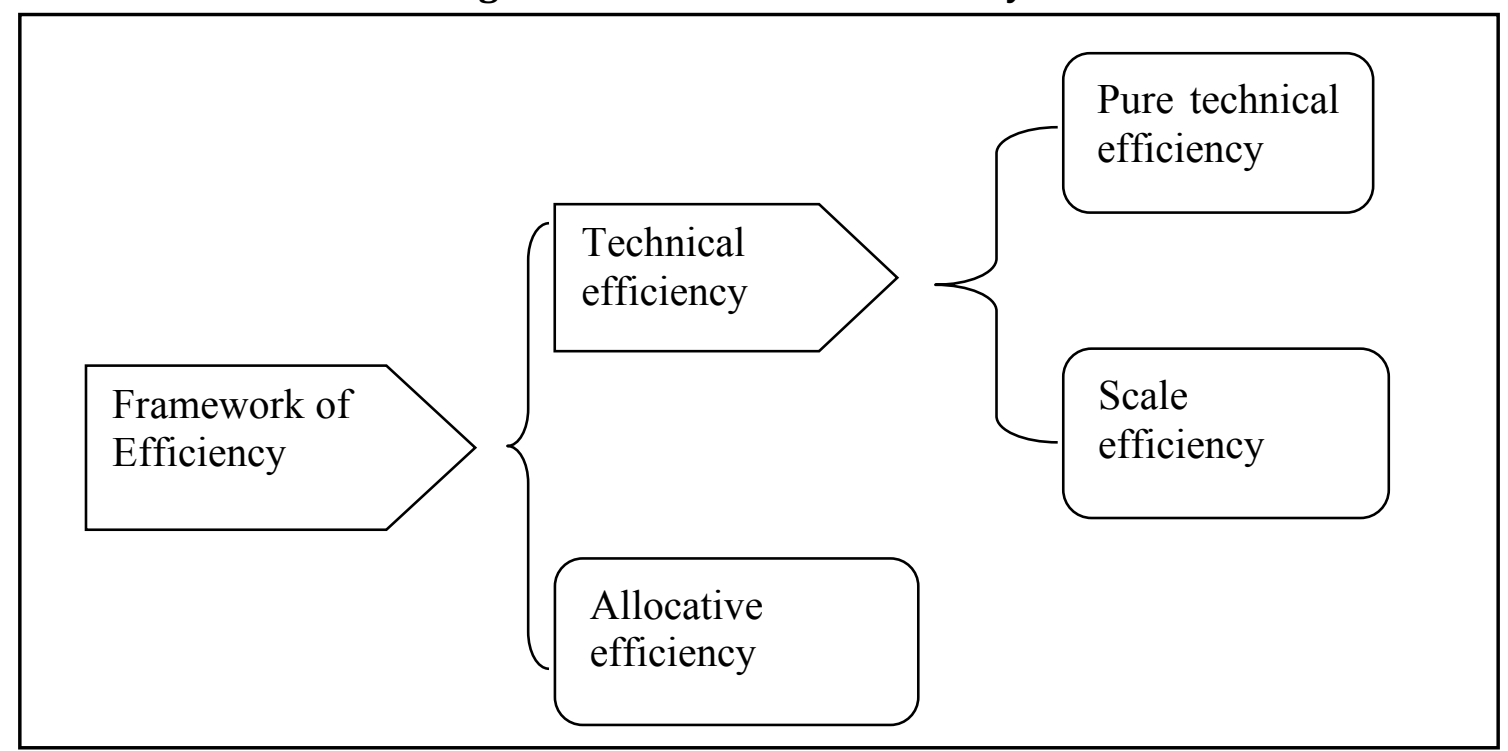

Source: Farrell 1996

Thus, in general, technical efficiency is further decomposed into measures of (PTE) and (SE) and the concept of SE determines whether or not the firm operates at an optimum size and in order to measure scale efficiency, the assumption of VRS replaces CRS. While allocative efficiency (AE) shows the firms ability to use inputs in optimal proportions (Farrell, 1996, Markovits, 2008). The Figure 2 shows the framework of efficiency. The study utilizes only technical efficiency which decompose to pure technical efficiency and scale efficiency, but it excludes Allocative efficiency (AE) due to unavailability of data.

\section{RESEARCH METHODOLOGY}

There are several studies on measuring the efficiency of banking sector globally as commercial banks are operating in an increasingly competitive environment (Isik \& Hassan 2002; Mester 1997; Yeh, 1996). The long term capability of commercial banks operating in this environment relies on how efficiently they are being run. The efficient and effective use of resources is a key objective of every banker. With global trends of rising competition for financial services, deregulation, technological innovations and banking consolidation has brought more consideration on controlling costs and providing products and services more efficiently (Karim \& Gee 2007). The most broadly methods in use are the parametric SFA and non-parametric DEA while other studies focus only on TE which comprised of PTE, SE and AE. Also, similar methods have been used in Africa (Hauner \& Peiris, 2005; Aikael, 2008; Bokola, 2009; and Frimpong, 2011) using DEA and (Siyaka, 2006; Hiroyuki, 2009 and Mostafa, 2008) using SFA, descriptive analysis and various accounting ratios.

This study uses DEA relative efficiency of commercial banks in the Gambia during the period 2005-2009 in terms of TE (PTE and SE). However, the study is able to measure the efficiency of an Islamic bank among CCBs within the industry.

The efficiency measures of TE, PTE and SE are regressed with bank characteristics to find the main factors that influence the level of efficiency of CBs in The Gambia. 


\section{Sample Selection and Data Sources}

The sample consists of seven (7) commercial banks including an Islamic bank out of 12 for the selected period 2005-2009, as follows: (1) Standard Chartered Bank (Gambia) Ltd, (2) Arab Gambian Islamic bank, (3) Trust Bank Ltd, (4) First International Bank, (5) Guaranty Trust Bank (6) International Commercial Bank and (7) Bank PHB as shown in Table 1. The data is a secondary accessed from the banks' annual audited financial report from 2005-2009 end December data.

\section{Table 1: List of Commercial banks in the Study}

\section{No. Bank Name}

1 Standard Chartered Bank (Gambia) Ltd

2 Arab Gambia Islamic Bank

3 Trust Bank Ltd

$4 \quad$ First International Bank

5 Guaranty Trust Bank (Gambia) Ltd

6 International Commercial Bank (Gambia) Ltd

7 Bank PHB/IBC

\section{Established}

1894

1996

1997

1999

2002

2005

$1997 / 2008$

Abbreviation Used
SCBG
AGIB
TBL
FIB
GTB
ICB
PHB

The seven banks were selected as they are the only banks that were fully operational during the five year period.

\section{First stage DEA}

This study applies DEA is a non-parametric approach to measure the efficiency of commercial banks in The Gambia. The DEA model was developed by Charnes, et al., (1987) involves the calculation of efficiency by comparing the inputs/outputs ratio of each firm. DEA can be measured by an input-oriented procedure, which focuses on reducing inputs to produce the same level of outputs, and an output-oriented procedure, which aims to maximize outputs from the same set of inputs (Coelli, 1996)

Due to its increasing popularity in bank efficiency study, DEA is the selected approach in this study. DEA is adopted in this study as it is capable of handling multi-outputs and multi-inputs setting. Another reason for choosing the DEA approach is its comparative robust (Seiford \& Thrall, 1990). The main purpose of DEA is to measure the relative productivity of each DMU by comparing it with every decision making unit (DMU) used in the model. For each input and output of every DMU, weights are assigned and analysed to arrive at an efficiency score. Indeed, efficiency score is the weighted sum of outputs divided by weighted sum of inputs..

This study uses the software, DEAP version 2.1 that has been developed by Coelli $(1996,2005)$ to estimate TE, PTE and SE. The TE under the assumption of VRS expresses the (local) TE (i.e. PTE) (Cooper et al., 2000 as stated by Zamil, 2007):

Decomposition of Technical Efficiency

Technical Efficiency (TE) = Pure Technical Efficiency (PTE) and Scale Efficiency (SE)

Source: (Zamil, 2007)

If a DMU is fully efficient (100\%) in both the CRS and VRS assumptions is operating in the most productive scale size (MPSS) (Cooper et al., 2000). In addition, if a DMU is efficient under the 
VRS assumption but inefficient under the CRS assumption, then it is locally efficient but not globally efficient due to the scale size of the DMU (Cooper et al., 2000; Zamil, 2007) ${ }^{3}$

\section{DEA Model}

Using DEA model, we first consider that $\mathrm{N}$ banks or also known as decision making units (DMUs) each producing $S$ different outputs using $t$ different inputs. The efficiency of the DMUs measured as follows:

$$
e f_{p}=\sum_{i=1}^{s} u_{i} y_{i p} / \sum_{j=1}^{t} v_{j} x_{j p}
$$

Where $y_{i p}$ is the amount of the $i^{\text {th }}$ output produced by the $p^{\text {th }} \mathrm{DMU}, x_{j p}$ is the amount of the $j^{\text {th }}$ input used by the $p^{\text {th }} \mathrm{DMU}, u_{i}$ is the input weight, $v_{j}$ is the input weight , $i$ runs from 1 to $\mathrm{s}$, and $\mathrm{j}$ runs from 1 to $\mathrm{t}$. This efficiency ratio $\left(e f_{p}\right)$ is then maximized subject to the following:

$$
\sum_{i=1}^{s} u_{i} y_{i r} / \sum_{j=1}^{t} v_{i} y x_{j r} \leq 1, \quad \text { for } r=1, \ldots, N \text { and } u_{i} \text { and } v_{j} \geq 0
$$

Where the first inequality ensures that the efficiency ratios for the other DMUs would not exceed at once, while the second inequality requires that the weights are positive, the weights for each output are determined so that each DMU maximizes its own efficiency ratio

The fractional linear program can be transformed into an ordinary linear program as follows:

$$
\begin{aligned}
& \text { Maximize } e f_{p}=\sum_{i=1}^{s} u_{i} y_{i p} \\
& \text { Subject to } \sum_{i=1}^{s} u_{i} y_{i r} / \sum_{j=1}^{t} v_{j} x_{j r} \leq 0, \quad r=1, \ldots, N ; \\
& \sum_{j=1}^{t} v_{j} x_{j p}=1 \text { and } u_{i} \text { and } v_{j} \geq 0 .
\end{aligned}
$$

Or the dual problem as follows:

$$
\text { Minimize } \quad \beta_{p}
$$

Subject to $\quad \sum_{r=1}^{N} \emptyset_{r} y_{i r,} \geq y_{i p,} i=1, \ldots, s$;

$$
\beta_{p} x_{j p}-\sum_{r=1}^{N} \emptyset_{r} x_{i r} \geq 0, j=1, \ldots, t ; \emptyset_{r} \geq 0 ; \text { and } \beta_{p} \text { free } \text {. }
$$

3 Efficiency of Islamic and conventional commercial banks in Malaysia (2000-2004): A data envelopment analysis (DEA) study. 
The variable $\beta_{P}$ is the overall technical efficiency and must lie between zero and one.. The linear programming problem outlined in (v) and (vi) assumes constant returns to scale (CRS) The solution to the CRS problem in (v) and (vi) is frontier 0CRS . A bank on this frontier is an efficient bank, while bank $\mathrm{p}$ located inside the frontier at point $\mathrm{P}$ is inefficient,. In this event, the overall technical efficiency $\left(\beta_{p}\right)$ is measured by the ratio $\mathrm{AB} / \mathrm{AP}$, which is less than 1 . Thus, (1$\beta_{p}$ ) gives the function by which inputs must be reduced to produce the same output as the efficient bank at point B.

\section{Input and Output Identification}

The main difficulty in measuring efficiency of commercial banks is how to select input and output of the bank, due to disagreement of what exactly banks produced (Berger \& Humphrey, 1992). if the $\mathrm{n}$ is lower than $\mathrm{m}+\mathrm{s}$ that means the large portion of the DMUs will be explained as efficient and efficiency discrimination among the DMUs is consider lost (Cooper et al., 2000; Zamil,2007).

Table 2: Inputs And Outputs of the Study

\begin{tabular}{|c|c|c|}
\hline $\begin{array}{l}\text { Variable } \\
\text { Inputs }\end{array}$ & Variable name & $\begin{array}{l}\text { Definition } \\
\text { Dalasis' } 000\end{array}$ \\
\hline $\mathrm{X} 1$ & Labour & $\begin{array}{l}\text { Operating expenses as a proxy for personnel costs (Sok-Gee, } \\
\text { 2011) }\end{array}$ \\
\hline $\begin{array}{l}\mathrm{X} 2 \\
\text { Outputs }\end{array}$ & Total deposits & Deposits and customer deposits \\
\hline Y1 & Loans \& advances & Loans \& advances.(account receivable for AGIB) \\
\hline Y2 & Income & $\begin{array}{l}\text { Total interest income, non interest income and income from } \\
\text { AGIB (Grigorian \& Manole, } 2002 \text { and Zamil,2007) }\end{array}$ \\
\hline
\end{tabular}

Under the asset approach, banks are considered as financial intermediaries by utilising liability(deposits) as source to finance assets (debtors). Loans and other assets are considered to be bank outputs; deposits and other liabilities are inputs in the intermediation process (Sealey etal 1997; Berger \& Humphrey, 1992).

On the other hand, the study will focus only on evaluating the TE, PTE and SE, by using DEA method. The inputs will be operating expenses as proxy to labour, due to the unavailability of personnel costs in some bank financial statements.

\section{Statistical Regression}

The study aims to include regression to test various factors that may have significant impact in banking efficiency - such as bank size, bank profitability and market power. The relationship between these factors with banking efficiency is examined by employing available data extracting from non-parametric methods in line with the works of Zamil, (2007); Aly, et al., (1990); Berger \& DeYoung, (1997); Isik \& Hassan, (2003); Miller \& Noulas, (1996); Sathye,( 2001) 


\section{Variables measurement}

Figure 3:The relationship between independent variables and dependent variables.

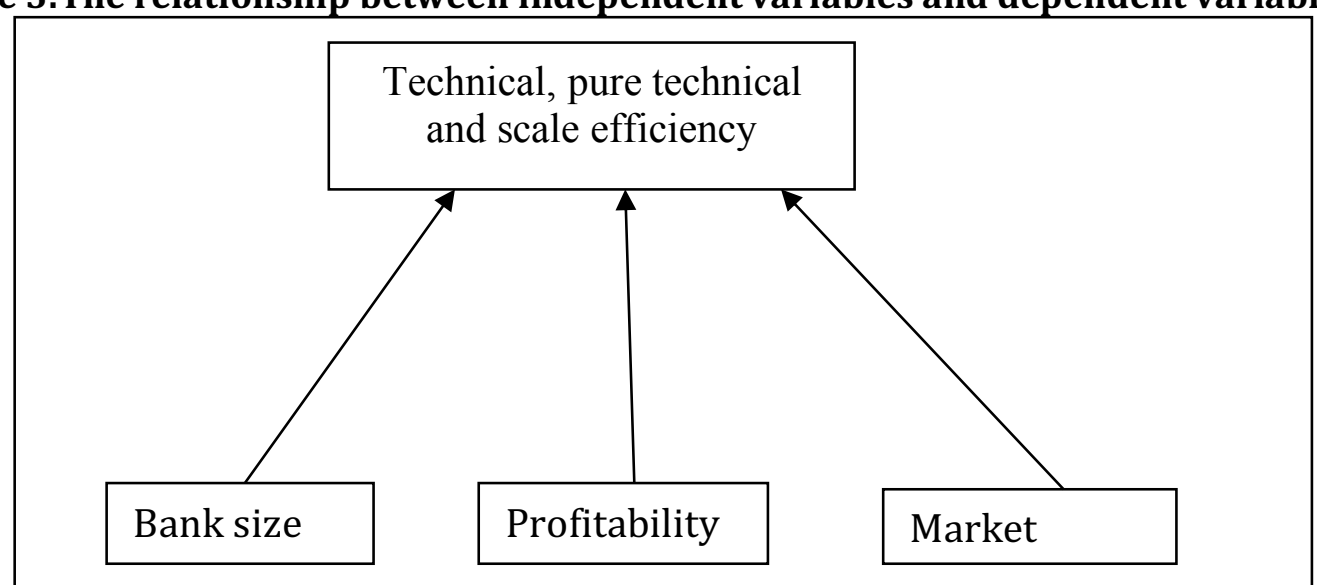

Source: Zamil 2007

The Table 4 illustrates the dependent variables of the study

\section{Dependent variables and their definition}

Table, 4: Dependent variables and their definition.

\begin{tabular}{ll}
\hline $\begin{array}{l}\text { Dependent } \\
\text { Variables }\end{array}$ & Explanation Of The Dependent Variables \\
\hline TE & $\begin{array}{l}\text { Technical efficiency, PTE and SE. using equal or less of all inputs to } \\
\text { produce a given output, as compared to the bank on the efficiency } \\
\text { frontier (under management control ) } \\
\text { PTE }\end{array}$ \\
$\begin{array}{l}\text { Pure technical efficiency, TE/SE, TE under the variable returns to scale } \\
\text { (VRS), i.e. TE that is devoid of SE effects. }\end{array}$ \\
$\begin{array}{l}\text { Scale efficiency, TE/PTE , whether a bank has the right size, i.e. whether } \\
\text { it produces where the long-run average curve (LRAC) i.e. minimum , or } \\
\text { where CRS is observed }\end{array}$ \\
\end{tabular}

Independent variables

The table 4.6 illustrates the independent variables of this study (modified from Zamil, 2007)

Table 5: Independent variables and explanation of independent variables

\begin{tabular}{ll}
\hline $\begin{array}{l}\text { Independent } \\
\text { Variables }\end{array}$ & Explanation of Independent Variables \\
\hline Bank Size & Total Assets of the bank \\
Profitability & Net operating income to total assets \\
Market Power & Bank deposits to total industry deposits \\
\hline
\end{tabular}

\section{Hypotheses development}

This study develops three hypotheses (Bank Size, Profitability and Market Power) that fit into The Gambian banking sector and available data. The next section focus on hypotheses formulation:

\section{Bank Size and Efficiency}

The study of the impact of size on the estimated efficiency levels of banks is a quite standard practice. Within the banking literature, size has often been found to be an important factor that drives variations in efficiency across banks. Several studies have found positive relationship between size and efficiency as larger banks are more flexible in the financial markets and are 
better able to vary their credit risks (Cole and Gunther, 1995, Dong, 2010), able to attract more professional management personnel thus more effective in cost control, resulting in higher profits ((Evanoff \& Israilevich, 1991). And are able to exploit economies of scale and scope from growth and joint production opportunities (Dong, 2010, Casu \& Girardone (2006).

However, larger banks are more difficult and therefore more complex to manage (Delis and Papanikolaou, 2009; Dong, 2010). Quite number of other studies find a significant negative relationship between size and banking efficiency and suggest that small banks may possess operational advantages that bring about higher efficiencies (Girardone, Molyneux, \& Gardener, 2004; Hermalin \& Wallace, 1994; Isik \& Hassan, 2002a; S. C. Kumbhakar \& Wang, 2007). Carrat et al., (2002) also argues that the divisibility theory holds that there will be no such operational advantage accruing to large banks, suggesting no association between size and efficiency.

The relationship between bank size and efficiency measures (adopted from Zamil,2007).

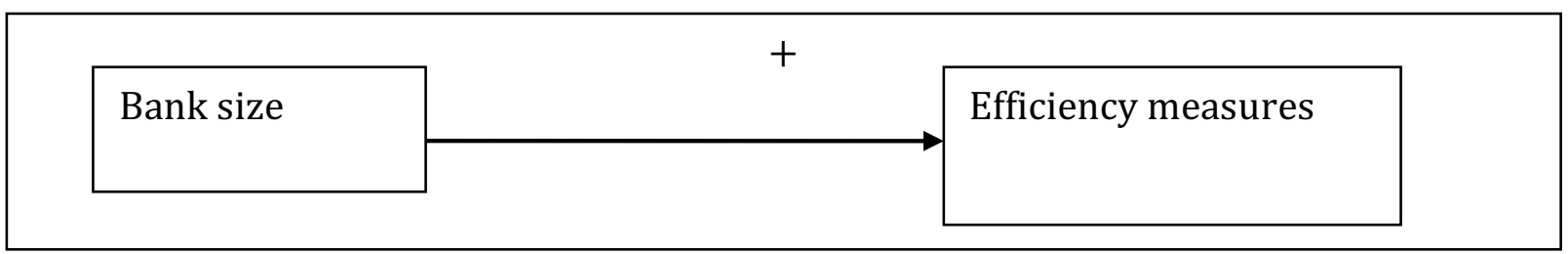

Therefore, the hypotheses can be formulated as follows:

H1: The larger the bank size, the higher the efficiency:

H1a: The larger the bank size, the higher the TE.

H1b: The larger the bank size, the higher the PTE.

H1C: The larger the bank size, the higher the SE.

\section{Bank Profitability and Efficiency.}

The impact of the profitability is generally positive to the level of efficiency (Miller \& Noulas, 1996). There are two different outcomes from a theoretical aspect of relationship between bank profitability and efficiency. The first one proposes that efficiency is the driving power in determining the structure of a market. In particular, the higher the efficiency level of a given firm, the higher the profits a firm can earn. Market dynamics involve more profitable firms gain higher market shares, and this in turn will lead to market attentiveness reporting a positive relationship between efficiency and profitability. Furthermore, in the literature, Darrat et al. (2002) found a significant positive relationship between banks' profitability and all kind of efficiency, (also see Hassan \& Marton; Hasan \& Marton, 2003; Miller \& Noulas, 1996, Maghyereh,(2004) due to the fact that the larger banks have ability to raise more capital.

On the contrary, a second circumstance suggests that in a concentrated industry, banks will create monopoly rents, thus reducing clients' welfare, since banks service charge increase will reduce the quantity of financial services supplied, thus welfare loss (Turati, 2003; Berger \& Hannan 1998, Turati, 2003).). Their paper suggests that with more concentrated markets, efficiency of banks are worsen as managers are not motivated to minimize costs.

The relationship between profitability and efficiency measures. (Source: Zamil,2007)

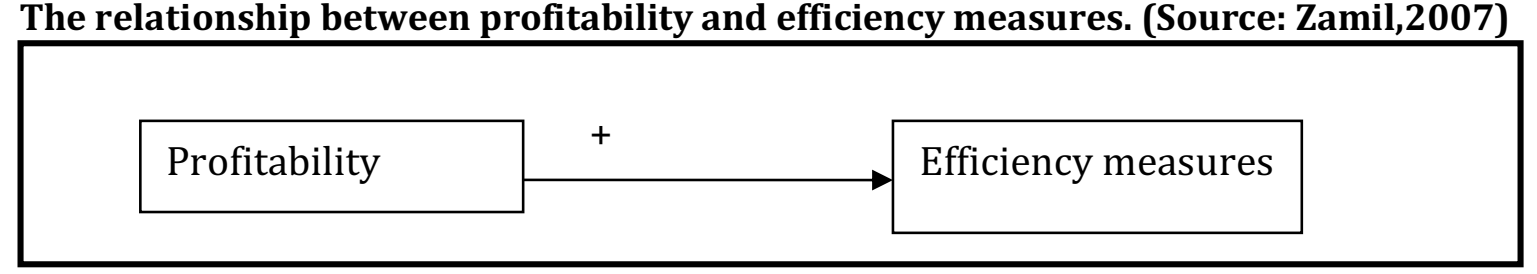


Therefore the hypotheses are formulated as:

$\mathrm{H} 2$ : The higher the profitability, the higher the efficiency:

H2a: The higher the profitability, the higher the TE

$\mathrm{H} 2 \mathrm{~b}$ : The higher the profitability, the higher the PTE

H2c: The higher the profitability, the higher the SE

\section{Market Power and Bank Efficiency}

It is important to investigate the impact of market power of bank on efficiency. However, previous studies focus on issues from the structure - conduct - performance (SCP) paradigm which relates firm behaviour and performance in terms of market structural characteristics such as number and size distribution of banks (Dong 2010)

Due to high profitability led by an inadequate level of competition, management may not control the costs of their operations to the optimal level possible. Also, market power may induce managers to costly preference behaviours ( plush offices, first class travel etc) that raise costs and reduce measured cost efficiency ( Dong, 2010; Isik \& Hassan, 2003)thus reporting negative relation with efficiency ( Dong, 2009; Isik \& Hassan , 2003, Sathye 2001 and Maghyereh 2009)

However, Darrat et al, (2002) found that market power in the Kuwaiti banking industry leads to a significant development in cost efficiency, also see (Gregorian \& Manole 2002; Katib,1990; Zamil, 2007, Smirlock ,1985; Timme \& Yang ,1991; Berger,1995, Isik \& Hassan,2003). In this study, market power is measured by the bank's deposits to total bank industry deposits of the banking sector in The Gambia.

The relationship between market power and efficiency measures. Source: (Zamil,2007) .

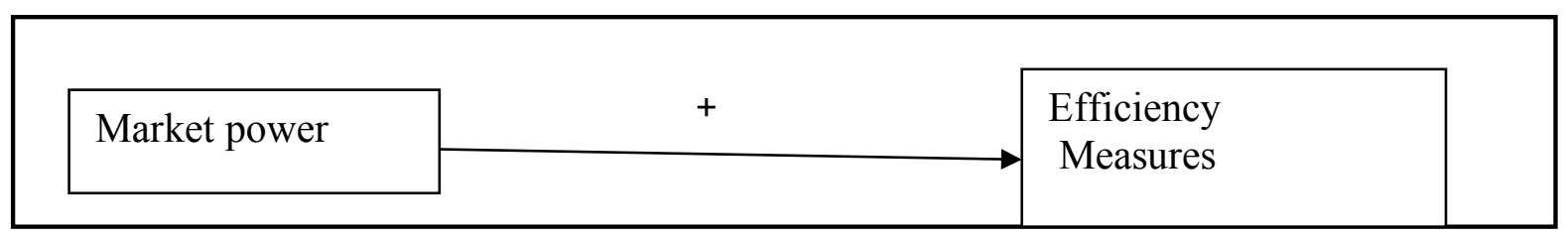

Therefore, the hypotheses are assumed as:

H3: The larger the market power, the higher the efficiency:

H3a: The larger the market power, the higher the TE.

H3b: The larger the market power, the higher the PTE.

H3c: The larger the market power, the higher the SE.

\section{Model development}

The second stage of efficiency is analysed to determine the impact of variables on efficiency measures, (see table $4.4 \& 4.5$ ), the model that will be used in this study as linear regression is:

$$
E f=\alpha+\beta 1 S+\beta 2 P+\beta 3 M
$$

Where:

Ef= Overall, Technical Efficiency.

$\mathrm{S}=$ Bank Size.

$\mathrm{P}=$ Profitability.

$\mathrm{M}=$ Market Power 


\section{DATA ANALYSIS AND EMPIRICAL RESULTS}

The findings of input and output analysis, DEA, descriptive analysis, linear regression and hypothesis tests are presented in this section.

\section{DEA: Efficiency of Commercial Banks in the Gambia}

\section{Sample characteristics.}

Table 6 shows the descriptive statistics of inputs and outputs of 7 commercial banks in The Gambia including one Islamic bank over the period.

Table 6: Descriptive statistics of inputs and outputs of selected banks, 2005-2009 (Dalasi.'000)

\begin{tabular}{lccccc}
\hline & Mean & Median & Maximum & Minimum & Std. Deviation \\
\hline $\begin{array}{l}\text { Inputs } \\
\begin{array}{l}\text { Operating } \\
\text { expenses }\end{array}\end{array}$ & $91,393.29$ & $54,751.00$ & 247,009 & 10,725 & $75,257.243$ \\
Total deposits & $883,838.31$ & $444,631.00$ & $2,477,150$ & 58,973 & $821,045.796$ \\
\hline $\begin{array}{l}\text { Outputs } \\
\begin{array}{l}\text { Loans \& } \\
\text { advances }\end{array}\end{array}$ & $314,157.80$ & $184,972.00$ & $1,102,961$ & 8,252 & $280,832.208$ \\
Income & $155,069.86$ & $82,779.00$ & 418,514 & 15,003 & $140,252.751$ \\
\hline
\end{tabular}

On average, total deposits and loans and advances are the most prominent input and output in Gambian banking industry. Of 7 commercial banks, TBL is found to get the highest numbers of inputs and outputs while ICB recorded the lowest level of inputs and outputs associated mainly with it being the newest bank commencing operations in 2005 .

Table 7 reveals the descriptive statistics of the efficiency measures throughout 35 observations. As noted from the Table, the minimum TE and SE are scored by ICB, while minimum TPE is scored by PHB in 2005.

Table 7: Descriptive Statistics: Efficiency Measures

\begin{tabular}{llllll}
\hline & Sample & Minimum & Maximum & Mean & Std. Deviation \\
\hline TE & 35 & 0.219 & 1.000 & 0.904 & 0.183 \\
PTE & 35 & 0.667 & 1.000 & 0.972 & 0.080 \\
SE & 35 & 0.219 & 1.000 & 0.930 & 0.169 \\
\hline
\end{tabular}

\section{Efficiency Measures: Input Orientation}

Table 8 shows the means of TE under the assumption of CRS and PTE, and SE under the assumption of VRS. The TE mean under the assumption of CRS ranged from $66.6 \%$ and $96.8 \%$, meaning the banks on average could have produced the same level of output by actually using only $90.4 \%$ of the inputs mix. In other words, it can be stated that on average the banks were still 3.2\% technically inefficient in 2009. Since the banks were operating under CRS, much of their technical inefficiency was attributed to input wastage.

However, under the assumption of VRS, the PTE ranged between $90.3 \%$ and $100 \%$ during the period, also the SE ranged from $75.7 \%$ and $98.7 \%$. 
Table 8:Technical Efficiency in Gambian Banking: 2005-2009, CRS, VRS

\begin{tabular}{ccccc} 
Year & $\begin{array}{l}\text { Sample } \\
\text { size }\end{array}$ & $\begin{array}{c}\text { Technical } \\
\text { efficiency } \\
\text { Mean of sample } \\
\text { CRS }\end{array}$ & $\begin{array}{c}\text { Pure technical } \\
\text { efficiency } \\
\text { Mean of sample } \\
\text { VRS }\end{array}$ & $\begin{array}{c}\text { Scale efficiency } \\
\text { Mean of sample }\end{array}$ \\
\hline 2005 & 7 & 0.666 & 0.903 & 0.757 \\
2006 & 7 & 0.955 & 0.974 & 0.980 \\
2007 & 7 & 0.977 & 0.990 & 0.987 \\
2008 & 7 & 0.958 & 0.996 & 0.961 \\
2009 & 7 & 0.968 & 1.000 & 0.968 \\
\hline
\end{tabular}

\section{Technical Efficiency -Assumption of CRS}

Table 9 describes TE measured by using DEA method under assumption of CRS showing TBL consistently efficient throughout the selected period recording the highest mean of TE at an annual average level of 1 . Furthermore, the Islamic bank AGIB came second with an annual average level of $96.9 \%$, then FIB follows with an annual average of level of $95.9 \%$. GTB and PHB followed with an annual average level of $89.5 \%$ and $89.4 \%$ respectively, while ICB recorded lowest TE with an annual average level of $77.3 \%$. Therefore, in general all banks obtain the TE level of $90.5 \%$ for the period of 2005-2009 except SCBG, GTB, ICB and PHB. Overall, the banking industry scored the highest level of TE in 2007, while the lowest level occurred in 2005, with an annual average of $97.7 \%$ and $66.6 \%$ respectively (see Table 9).

Table 9:Technical Efficiency of the commercial banks, 2005-2009 (CRS)

\begin{tabular}{llllllll} 
No & Bank & 2005 & 2006 & 2007 & 2008 & 2009 & MEAN \\
\hline 1 & SCB & 0.358 & 0.931 & 1.000 & 1.000 & 0.913 & 0.840 \\
2 & TBL & 1.000 & 1.000 & 1.000 & 1.000 & 1.000 & 1.000 \\
3 & GTB & 0.638 & 0.841 & 1.000 & 1.000 & 1.000 & 0.895 \\
$\mathbf{4}$ & AGIB & $\mathbf{1 . 0 0 0}$ & $\mathbf{1 . 0 0 0}$ & $\mathbf{1 . 0 0 0}$ & $\mathbf{0 . 9 8 7}$ & $\mathbf{0 . 8 6 0}$ & $\mathbf{0 . 9 6 9}$ \\
5 & FIB & 0.828 & 0.967 & 1.000 & 1.000 & 1.000 & 0.959 \\
6 & ICB & 0.219 & 0.957 & 0.929 & 0.762 & 1.000 & 0.773 \\
7 & PHB & 0.621 & 0.985 & 0.913 & 0.955 & 1.000 & 0.894 \\
\hline & MEAN & 0.666 & 0.95 & 0.977 & 0.958 & 0.968 & 0.905
\end{tabular}

\section{Pure Technical Efficiency (Under VRS)}

Table 10 showed PTE of commercial banks in The Gambia using DEA under the assumption of VRS. As noted from the Table 10 SCB, TBL, AGIB and ICB are consistently efficient throughout the five years period, since each of them scored an annual average of 1, the highest level of PTE. Thus, we can conclude that these banks are the most efficient banks in terms of PTE, with GTB recording the last PTE of 90.5 .

Table 10:Pure Technical Efficiency of the commercial banks, 2005-2009 (VRS)

\begin{tabular}{cccccccc} 
No & bank & 2005 & 2006 & 2007 & 2008 & 2009 & MEAN \\
\hline 1 & SCB & 1.000 & 1.000 & 1.000 & 1.000 & 1.000 & 1.000 \\
2 & TBL & 1.000 & 1.000 & 1.000 & 1.000 & 1.000 & 1.000 \\
3 & GTB & 0.679 & 0.847 & 1.000 & 1.000 & 1.000 & 0.905 \\
$\mathbf{4}$ & AGIB & $\mathbf{1 . 0 0 0}$ & $\mathbf{1 . 0 0 0}$ & $\mathbf{1 . 0 0 0}$ & $\mathbf{1 . 0 0 0}$ & $\mathbf{1 . 0 0 0}$ & $\mathbf{1 . 0 0 0}$ \\
5 & FIB & 0.976 & 0.972 & 1.000 & 1.000 & 1.000 & 0.989 \\
6 & ICB & 1.000 & 1.000 & 1.000 & 1.000 & 1.000 & 1.000 \\
7 & PHB & 0.667 & 1.000 & 0.929 & 0.975 & 1.000 & 0.914 \\
\hline & MEAN & 0.903 & 0.974 & 0.989 & 0.996 & 1.000 & 0.973
\end{tabular}




\section{Scale Efficiency}

Table 11 showed the SE of commercial banks in The Gambia during the period reporting TBL as the most consistently efficient bank with no amount scale inefficiency. GTB followed with an annual average of $98.6 \%$,PHB with $97.6 \%$, and the least SE bank being ICB with just $77.3 \%$. Generally, all banks obtained the average SE level of 93.0\% during the period 2005-2009 except SCBG and ICB.

Table 11:Scale Efficiency of the commercial banks, 2005-2009 (SE)

\begin{tabular}{cccccccc} 
No & bank & 2005 & 2006 & 2007 & 2008 & 2009 & MEAN \\
\hline 1 & SCB & 0.358 & 0.931 & 1.000 & 1.000 & 0.913 & 0.840 \\
2 & TBL & 1.000 & 1.000 & 1.000 & 1.000 & 1.000 & 1.000 \\
3 & GTB & 0.939 & 0.994 & 1.000 & 1.000 & 1.000 & 0.986 \\
$\mathbf{4}$ & AGIB & $\mathbf{1 . 0 0 0}$ & $\mathbf{1 . 0 0 0}$ & $\mathbf{1 . 0 0 0}$ & $\mathbf{0 . 9 8 7}$ & $\mathbf{0 . 8 6}$ & $\mathbf{0 . 9 6 9}$ \\
5 & FIB & 0.849 & 0.996 & 1.000 & 1.000 & 1.000 & 0.969 \\
6 & ICB & 0.219 & 0.957 & 0.929 & 0.762 & 1.000 & 0.773 \\
7 & PHB & 0.932 & 0.985 & 0.983 & 0.98 & 1.000 & 0.976 \\
\hline & MEAN & 0.757 & 0.980 & 0.987 & 0.961 & 0.968 & 0.930
\end{tabular}

Table 12 describes TE, PTE and SE of commercial banks in The Gambia in five year period. It's clear from the Table that TBL is the only bank that has reached AN efficient level of 1 in all efficiency measures - TE, PTE and SE. Thus, it could be indicated that TBL is the most efficient bank in The Gambia during the analysis period. On the other hand, the table illustrates that SCB, AGIB and ICB are totally efficient in terms of PTE only, but are inefficient in terms of TE and SE.

Table 12: Overall Efficiency of commercial banks TE, PTE and SE 2005-2009

\begin{tabular}{cccc}
\hline Bank & TE & PTE & SE \\
\hline SCB & 0.840 & 1.000 & 0.840 \\
TBL & 1.000 & 1.000 & 1.000 \\
GTB & 0.895 & 0.905 & 0.986 \\
AGIB & 0.969 & 1.000 & 0.969 \\
FIB & 0.959 & 0.989 & 0.969 \\
ICB & 0.773 & 1.000 & 0.773 \\
PHB & 0.894 & 0.914 & 0.976 \\
\hline
\end{tabular}

The results of this study are consistent with economic condition in the Gambia. The Gambian economy has witnessed a stable development during the analysis period. In 2003-2006 the country GDP growth was 6.4\%, (Sanyang, 2009, ADB, 2008). IMF (2007) reported that the "Real GDP growth averaged 6.2 percent for 2004-06, influenced by growth in the tourism, construction, and telecommunications sectors"

Therefore, the results of the current study have confirmed correlation between the economic growth and efficiency growth of commercial banks in the Gambia in 2007, while almost all banks scored efficiency annual average level of 1 . 
The banking industry ${ }^{4}$ witnesses growth in total assets, deposits and loan and advances (see Tables 10,11). Thus, indicating that the results from efficiency measures are consistent with growth of banking sector particularly from 2007-2009.

Table 13:Assets, deposits and loans and advances growth in Gambian banking industry

\begin{tabular}{lccccc}
\hline & 2005 & 2006 & 2007 & 2008 & 2009 \\
\hline Total Assets & $6,349,128$ & $7,504,451$ & $8,258,265$ & $8,723,421$ & $9,829,017$ \\
Total Deposits & $4,812,181$ & $5,671,490$ & $6,123,453$ & $6,620,823$ & $7,706,394$ \\
Total Loans and & & & & & \\
Advances & $1,567,429$ & $1,855,281$ & $2,050,850$ & $2,514,709$ & $3,007,254$ \\
\hline
\end{tabular}

\section{Descriptive Analysis}

Table 14 shows the descriptive statistics of the dependent variables and independent variables. The study utilizes ROA as proxy of profitability.

Table 14: Descriptive statistics: dependent variables (DV) and independent variables (IV)

\begin{tabular}{llllll}
\hline & Sample & Minimum & Maximum & Mean & Std. Deviation \\
\hline TE & 35 & 0.219 & 1.000 & 0.905 & 0.183 \\
PTE & 35 & 0.667 & 1.000 & 0.973 & 0.080 \\
SE & 35 & 0.219 & 1.000 & 0.931 & 0.169 \\
Bank Size & 35 & 137,294 & $2,939,358$ & $1,161,836.63$ & $975,787.176$ \\
Profitability & 35 & -0.0464 & 0.0500 & 0.0092 & 0.0248 \\
Market Power & 35 & 0.0019 & 0.0801 & 0.0286 & 0.0265 \\
\hline
\end{tabular}

In assessing the impact of the banks' characteristics on the efficiency of commercial banks in The Gambia, Multi-collinearity Test was conducted to show valid and reliable results using Tobit regression.

\section{Linear regression}

The independent variables of this study are Bank Size, Profitability ${ }^{5}$ and Market Power. Bank Size defined as the ratio of bank's assets to total ban industry assets in The Gambia and ROA used as proxy of profitability, while market power defined as ratio of bank's deposits to total bank industry deposits

\section{Dependent variable: Technical Efficiency}

Table 15 showed Tobit regression statistics for the regression of the independent variables on TE. The results showed an R-squared of 0.285 indicating $29 \%$ of selected variables is explained by TE scores. Bank size is the only variable recording significant and positive relationship with TE at 5\%, while both Profitability (ROA) and MP showed no relationship with TE.

4 For 7 selected bank among 14 CBs in the Gambia .

${ }^{5}$ ROA is used as a proxy of Profitability. 
Table 15: Dependent variable: Technical Efficiency ${ }^{6}$

\begin{tabular}{cllll}
\hline & Coefficient & Std. Error & z-Statistic & Prob. \\
\hline \hline C & -3.312573 & 2.014576 & -1.644303 & 0.1001 \\
SIZE & 0.773402 & 0.366221 & 2.111847 & $0.0347^{* *}$ \\
ROA & -3.969419 & 2.792082 & -1.421670 & 0.1551 \\
MP & -6.396607 & 5.220807 & -1.225214 & 0.2205 \\
& & & \\
\hline \hline SCALE:C(5) & 0.250573 & 0.046755 & 5.359304 & 0.0000 \\
\hline \hline R-squared & 0.285243 & Mean dependent var & 0.904686 \\
Adjusted R-squared & 0.189942 & S.D. dependent var & 0.183130 \\
\hline
\end{tabular}

Indicators: ( $\mathrm{C}=$ Constant) , Bank Size, profitability and market power

*Significant level bellows $0.01,{ }^{* *}$ Significant level bellows 0.05 , ***Significant level bellows 0.10

\section{Dependent variable: pure Technical Efficiency}

Table 16 exhibits the Tobit regression statistics for the regression of the independent variable on PTE. The R-squared of 0.227 reporting $23 \%$ of the variation in PTE is explained by this set of variables. The results show ROA, Size and MP are significantly related to PTE at $1 \%$ though only MP reported positive relationship.

Table 16: Dependent variable: pure Technical Efficiency

\begin{tabular}{cllll}
\hline \hline & Coefficient & Std. Error & z-Statistic & Prob. \\
\hline \hline C & 5.526330 & 1.255048 & 4.403283 & 0.0000 \\
SIZE & -0.817087 & 0.230204 & -3.549401 & $0.0004^{*}$ \\
ROA & -9.842355 & 3.793739 & -2.594368 & $0.009^{*}$ \\
MP & 24.26230 & 6.115967 & 3.967043 & $0.0001^{*}$ \\
\hline \hline SCALE:C(5) & 0.172087 & 0.044549 & 3.862844 & 0.0001 \\
\hline \hline R-squared & 0.227820 & Mean dependent var & 0.972714 \\
Adjusted R-squared & 0.124863 & S.D. dependent var & 0.080130 \\
\hline
\end{tabular}

Indicators: ( $\mathrm{C}=$ Constant), Bank Size, profitability and market power

*Significant level bellows $0.01,{ }^{* *}$ Significant level bellows $0.05,{ }^{* * *}$ Significant level bellows 0.10

\section{Dependent variable: Scale Efficiency}

Using Tobit regression statistics to run regression of the independent variable on SE, Rsquared recorded 0.296 meaning $30 \%$ of the variation in SE is explained by this set of variables. The results show that bank size and MP are significantly and positively related to SE while Profitability (ROA) show no relationship.

${ }^{6}$ The table from Eview5 using Tobit regression, Using 5years DEA efficiency score with 35 observations after eliminating the extra indicators. 
Table 17: Dependent variable: Scale Efficiency

\begin{tabular}{cllll}
\hline \hline & Coefficient Std. Error & z-Statistic & Prob. \\
\hline \hline C & -3.881777 & 2.032466 & -1.909885 & 0.0561 \\
SIZE & 0.886175 & 0.368489 & 2.404893 & $0.0162^{* *}$ \\
ROA & -2.165893 & 2.507505 & -0.863764 & 0.3877 \\
MP & 9.754380 & 4.854276 & 2.009441 & $0.0445^{* *}$ \\
\hline \hline SCALE:C(5) & 0.224894 & 0.055932 & 4.020845 & 0.0001 \\
\hline \hline
\end{tabular}

R-squared $\quad 0.296362$ Mean dependent var $\quad 0.093068$

Adjusted R-

squared

0.202544 S.D. dependent var

0.016992

*Significant level bellows $0.01,{ }^{* *}$ Significant level bellows $0.05,{ }^{* * *}$ Significant level bellows 0.10

\section{Hypotheses Test}

Table 18 provides the anticipated score and the summary of the linear regression results. The hypotheses that will be tested here are: bank size, profitability (ROA) and market power 


\begin{tabular}{|c|c|c|c|c|c|}
\hline \multirow[t]{2}{*}{ HYPOTHESES } & \multirow[t]{2}{*}{$\begin{array}{l}\text { EXPECTED } \\
\text { SIGN }\end{array}$} & \multicolumn{3}{|c|}{$\begin{array}{l}\text { RESULTS OF THE STUDY } \\
\text { EFFICIENCY LEVELS }\end{array}$} & \multirow[t]{2}{*}{$\begin{array}{l}\text { HYPOTHESES } \\
\text { TEST }\end{array}$} \\
\hline & & TE & PTE & SE & \\
\hline $\begin{array}{l}\text { H } 1 \text { the larger the bank size, the } \\
\text { higher the efficiency }\end{array}$ & & & & & ACCEPT \\
\hline $\begin{array}{l}\text { H1a: the larger the bank size, the } \\
\text { higher the TE. }\end{array}$ & + & $+* *$ & & & ACCEPT \\
\hline $\begin{array}{l}\text { H1b: the larger the bank size, the } \\
\text { higher the PTE. }\end{array}$ & + & & $-*$ & & REJECT \\
\hline $\begin{array}{l}\text { H1c: the larger the bank size, the } \\
\text { higher the SE }\end{array}$ & + & & & $+* *$ & ACCEPT \\
\hline $\begin{array}{l}\text { H } 2 \text { the higher the profitability, the } \\
\text { higher the efficiency }\end{array}$ & & & & & REJECT \\
\hline $\begin{array}{l}\text { H2a: the higher the profitability, the } \\
\text { higher the TE. }\end{array}$ & + & - & & & REJECT \\
\hline $\begin{array}{l}\text { H2b: the higher the profitability, the } \\
\text { higher the PTE. }\end{array}$ & + & & $-*$ & & REJECT \\
\hline $\begin{array}{l}\text { H2c: the higher the profitability, the } \\
\text { higher the SE. }\end{array}$ & + & & & - & REJECT \\
\hline $\begin{array}{l}\text { H } 3 \text { the lager the market power, the } \\
\text { higher the efficiency }\end{array}$ & & & & & REJECT \\
\hline $\begin{array}{l}\text { H3a: the larger the market power, the } \\
\text { higher the TE. }\end{array}$ & + & - & & & REJECT \\
\hline $\begin{array}{l}\text { H3b: the larger the market power, the } \\
\text { higher the PTE. }\end{array}$ & + & & $+^{*}$ & & ACCEPT \\
\hline $\begin{array}{l}\text { H3c: the larger the market power, the } \\
\text { higher the SE }\end{array}$ & + & & & $+* *$ & ACCEPT \\
\hline
\end{tabular}

\section{CONCLUSIONS}

The summary of average efficiency of CBs in the Gambia from 2005-2009 on the overall average TE, PTE and SE reported 90.4\%, 97.3\% and 93\% respectively. In this study the results exhibit that only one bank (TBL) is totally efficient under the assumption of CRS, and 4 banks out of 7 banks have achieved the average TE scores. Five banks (SCBG, TBL, AGIB, FIB, ICB) are PTE efficient while TBL, GTB, AGIB, FIB and PHB are SE (see Table 19).

The main causes of inefficiencies in The Gambia's banking sector are associated with high regulatory regime limiting lending and other investments, the oligopolistic market structure of two main banks - TBL and SCBG, the small banking market making the banking sector a bank centric system as opposed to a market centric system with the attendant diseconomies of scale, seemingly over-banked economy, competition, among others.

Table 19: Average Summary Of DEA Efficiency Of Commercial Banks - 2005-2009.

\begin{tabular}{lllll}
\hline No & Banks & TE & PTE & SE \\
\hline 1 & SCB & 0.840 & 1.000 & 0.840 \\
2 & TBL & 1.000 & 1.000 & 1.000 \\
3 & GTB & 0.895 & 0.905 & 0.986 \\
4 & AGIB & 0.969 & 1.000 & 0.969 \\
5 & FIB & 0.959 & 0.989 & 0.969 \\
6 & ICB & 0.773 & 1.000 & 0.773 \\
7 & PHB & 0.894 & 0.914 & 0.976 \\
\hline & MEAN & 0.904 & 0.973 & 0.930 \\
\hline \hline
\end{tabular}


This result of the study is consistent with other findings globally (Miller \& Noulas, 1996; Sturm \& william 2004 and Maghyereh 2004) also, (katib, 1999, Krishnasamy, Ridzwa, \& Perumal, 2004) found that scale inefficiency in Malaysian banks during 1989 to 1995 and 2000 to 2001 respectively. Aly et al (1990) and Darrat (2002) found technical inefficiency, the major contributor in the USA and Kuwait banking sector, due to operating wasting input and Sufian \& Ibrahim (2005) also found pure technical inefficiency contributed to Malaysian banks' postmerger TE from 2001to 2003.

\section{CONTRIBUTION OF THE STUDY}

This study is vital in many areas, being the first study to measure efficiency of commercial banks in The Gambia also using non-parametric method DEA in developing countries. The study for the first time measures an Islamic bank's efficiency among traditional banks. The study will be vital to policy-makers to know the relative efficiency levels of commercial banks in The Gambia and the factors that limit efficiency levels. In addition, it can help in ranking banks based on relative efficiency levels.

\section{SUGGESTIONS FOR FUTURE RESEARCH}

This study has its limitations like any other research. It will be important for future researchers focus on following:

1- The sample size may extend to cover all banks in the Gambia with longer time frame to show the real effect of efficiency measures.

2- Further researchers can employ more and different inputs and outputs instead of 2 inputs (i.e operating expenses and deposits) and 2 outputs (loans and advances and income) employed in this study. Also, other factors could be tested like Non-Performing Loans, Capitalization and Ownership factors instead of limiting to only Bank Size, Profitability and Market Power.

3- Further research could compare between large and small banks, foreign and local, in addition to Islamic and conventional banks.

4- Future research may use other methods to measure efficiency parametric method such as SFA, or comparison between Parametric and Non-Parametric methods instead of justy non-parametric DEA method used in this study.

5- Further researches may use cross-border studies to compare the efficiency of CBs in Gambia with CBs in other African counties in similar economic strength.

6- Assessing the importance of Islamic bank in the country, future studies could measure risk and solvency of AGIB and employ both primary survey questionnaire and interviews than just secondary data.

\section{References}

Agu, C. (2004). Efficiency of Commercial Banking in the Gambia. African Review of Money, Finance and Banking, 31-50.

Aly, H. Y., Grabowski, R., Pasurka, C., \& Rangan, N. (1990). Technical, scale, and allocative efficiencies in US banking: An empirical investigation. The Review of Economics and Statistics, 211-218.

Banker, R. D., Charnes, A., \& Cooper, W. W. (1984). Some models for estimating technical and scale inefficiencies in data envelopment analysis. Management science, 1078-1092.

Bashir, A. (2000). Determinants of profitability and rate of return margins in Islamic banks: some evidence from the Middle East.

Bauer, P. W., \& Hancock, D. (1993). The efficiency of the Federal Reserve in providing check processing services. Journal of Banking \& Finance, 17(2-3), 287-311.

Berger, A. N., \& DeYoung, R. (1997). Problem loans and cost efficiency in commercial banks. Journal of Banking \& Finance, 21(6), 849-870. 
Berger, A. N., \& Hannan, T. H. (1998). The efficiency cost of market power in the banking industry: A test of the "quiet life" and related hypotheses. Economics and Statistics, 80(3), 454-465.

Berger, A. N., \& Mester, L. J. (1997). Inside the black box: What explains differences in the efficiencies of financial institutions? Journal of Banking \& Finance, 21(7), 895-947.

Brown, K., Hassan, M. K., \& Skully, M. (2007). Operational efficiency and performance of Islamic banks. Handbook of Islamic banking, by M. Kabir Hassan and Mervyn K. Lews, 96-115.

Buchs, T., \& Mathisen, J. (2006). Competition and efficiency in banking: behavioral evidence from Ghana.

Chen, C. (2005). Bank Efficiency in Sub-Saharan African Middle Income Countries: International Monetary Fund.

Chen, X., Skully, M., \& Brown, K. (2005). Banking efficiency in China: Application of DEA to pre-and postderegulation eras: 1993-2000. China Economic Review, 16(3), 229-245.

Coelli, T. (1998). A multi-stage methodology for the solution of orientated DEA models. Operations Research Letters, 23(3-5), 143-149.

Cyert, R. M., \& March, J. G. (1992). A behavioral theory of the firm: Wiley-Blackwell.

Fadera, A. (2009). Islamic Banking in the Gambia: Developments, Challenges and Prospects: International Islamic University, Malaysia.

Frimpong, J. M. (2010). 'Investigating Efficiency of Ghana Banks: A Non-Parametric Approach. American Journal of Scientific Research, 7, 64-76.

Girardone, C., Molyneux, P., \& Gardener, E. P. M. (2004). Analysing the determinants of bank efficiency: the case of Italian banks. Applied Economics, 36(3), 215-227.

Hasan, I., \& Marton, K. (2003). Development and efficiency of the banking sector in a transitional economy: Hungarian experience. Journal of Banking \& Finance, 27(12), 2249-2271.

Hasan, Z. (2004). Measuring efficiency of Islamic banks: criteria, methods, and social priorities.

Hassan, T., Mohamad, S., \& Bader, M. K. I. (2009). Efficiency of conventional versus Islamic banks: evidence from the Middle East. International Journal of Islamic and Middle Eastern Finance and Management, 2(1), 46-65.

Isik, I., \& Hassan, M. K. (2002a). Cost and profit efficiency of the Turkish banking industry: An empirical investigation. Financial Review, 37(2), 257-279.

Kablan, S. (2007). Measuring bank efficiency in developing countries: the case of WAEMU (West African Economic Monetary Union). African Economic Research Consortium.

Kablan, S. (2010). Banking efficiency and financial development in Sub-Saharan Africa: International Monetary Fund.

Karim, M. Z. A. (2001). Comparative bank efficiency across select ASEAN countries. ASEAN Economic Bulletin, 289-304.

Levine, R. (2007). Financial Development and Economic Growth: Views and Agenda. Journal of Economic Literature, Vol. 35, No. 2., pp. 688-726.

Miller, S. M., \& Noulas, A. G. (1996). The technical efficiency of large bank production. Journal of Banking \& Finance, 20(3), 495-509.

Mostafa, M. (2007). Modeling the efficiency of GCC banks: a data envelopment analysis approach. International Journal of Productivity and Performance Management, 56(7), 623-643.

Rosly, S. A., \& Bakar, M. A. A. (2003). Performance of Islamic and mainstream banks in Malaysia. International Journal of Social Economics, 30(12), 1249-1265.

Samangi Bandaranayake, Samangi \& Jayasinghe, Prabhath (2013) Factors Influencing the Efficiency of Commercial Banks in Sri Lanka, Sri Lankan Journal of Management, Vol 18, Nos 1 \& 2,

Sanyang, L. (2009). Bank Strategic Positioning and Factors for Bank Selection- A Case of the Gambia International Master of Business Administration (IMBA), Ming Chuan University.

Seiford, L. M., \& Thrall, R. M. (1990). Recent developments in DEA:: The mathematical programming approach to frontier analysis. Journal of Econometrics, 46(1-2), 7-38.

Sillah, M. E. B. M. S. (2005). Banking and Economic Growth: Case of the Gambia. Doctor, Christian-AlbrechtsUniverstitaet zu Kiel. 
Sufian, F. (2007). The efficiency of Islamic banking industry in Malaysia: Foreign vs domestic banks. Humanomics, 23(3), 174-192.

Zamil, N. A. B. M. (2007). Efficiency of Islamic and conventional commercial banks in Malaysia (2000- 2004): A data envelopment analysis (DEA) study. Unpublished Masters Degree , International Islamic University Malaysia. 